\title{
THE APPLICATION OF LONG- AND SHORT-TERM PROGESTAGEN TREATMENTS FOR OESTROUS CYCLE CONTROL IN HEIFERS
}

\author{
J. M. SREENAN AND P. MULVEHILL \\ The Agricultural Institute, Belclare, Tuam, Co. Galway, Ireland
}

(Received 28th February 1975)

\begin{abstract}
Summary. Progestagen-impregnated pessaries were inserted into 205 heifers on eight farms. Treatments were either pessaries only for 20 days or pessaries for 10 days combined with an intramuscular injection of $250 \mathrm{mg}$ progesterone $+7.5 \mathrm{mg}$ oestradiol benzoate on the day of insertion. Pessary retention was low $(86.7 \%$ ) over the 20 -day period, but high $(93.6 \%)$ during the 10 -day period. Calving rates of heifers inseminated in oestrus following the 20-day treatment were low, while those of heifers inseminated on a fixed-time basis with the 10-day treatment were slightly higher than those of control heifers.
\end{abstract}

It has previously been shown that progestagen-impregnated vaginal pessaries inserted for 20 days can be used in cattle to synchronize oestrus, but low pessary retention and subnormal fertility rates have been reported (Wishart \& Hoskin, 1968; Sreenan, 1974, 1975). Retention of the pessaries was improved from $80 \%$ with a 20 -day treatment to $100 \%$ by a short-term (10-day) treatment associated with an initial intramuscular injection of progesterone and oestrogen (Sreenan, 1975).

The aim of the present study was to determine the effectiveness of longand short-term treatments with intravaginal progestagen-impregnated pessaries for oestrous cycle control and fertility under farm conditions.

Polyurethane sponge pessaries containing either $3.0 \mathrm{~g}$ progesterone or $0.15 \mathrm{~g}$ SG-9880 (Gronolone: G. D. Searle \& Co.) were prepared as previously described (Sreenan, 1975). All inseminations were carried out by technicians from commercial A.I. stations using frozen-thawed semen (about $30 \times 10^{6}$ spermatozoa/straw). The bulls used were chosen by each farmer and the fertility level was based on calving data.

In Trial 1, 110 heifers were treated on four farms during March to June 1973. Pessaries impregnated with progesterone or SC-9880 were inserted for 20 days. After removal of the pessary, oestrus was detected by the individual farmers who observed heifer to heifer behaviour. Animals observed in oestrus in the morning were inseminated that evening, and animals in oestrus in the evening were inseminated the following morning.

In Trial 2, 95 heifers were treated on four farms during November 1973 to April 1974. Progesterone-impregnated pessaries were inserted for 10 days. On 
the day of insertion, heifers received a combined intramuscular injection of $250 \mathrm{mg}$ progesterone $+7.5 \mathrm{mg}$ oestradiol benzoate in $10 \mathrm{ml}$ corn oil. Oestrous response was not checked and all the heifers were inseminated on a fixed-time basis, at 48 and $72 \mathrm{hr}$ after withdrawal of the pessary. A total of 51 untreated heifers in oestrus were inseminated on three of the farms during the treatment period and acted as controls.

Table 1. Oestrous response and calving rates in heifers after withdrawal of intravaginal progestagen-impregnated pessaries inserted for 20 days

\begin{tabular}{|c|c|c|c|c|c|c|c|c|}
\hline \multirow[b]{2}{*}{ Farm } & \multicolumn{4}{|c|}{ Progesterone-treated heifers } & \multicolumn{4}{|c|}{$S C-9880$-treated heifers } \\
\hline & $\begin{array}{c}\text { No. } \\
\text { treated }\end{array}$ & $\begin{array}{l}\text { No. with } \\
\text { retained } \\
\text { pessary }\end{array}$ & $\begin{array}{l}\text { No. in } \\
\text { oestrus }\end{array}$ & $\begin{array}{c}\text { No. } \\
\text { calving }\end{array}$ & $\begin{array}{c}\text { No. } \\
\text { treated }\end{array}$ & $\begin{array}{l}\text { No. with } \\
\text { retained } \\
\text { pessary }\end{array}$ & $\begin{array}{l}\text { No. in } \\
\text { oestrus }\end{array}$ & $\begin{array}{l}\text { No. } \\
\text { calving }\end{array}$ \\
\hline $\begin{array}{l}1 \\
2 \\
3 \\
4\end{array}$ & $\begin{array}{r}17 \\
11 \\
28 \\
4\end{array}$ & $\begin{array}{r}16 \\
8 \\
25 \\
3\end{array}$ & $\begin{array}{r}11 \\
7 \\
23 \\
2\end{array}$ & $\begin{array}{r}9 \\
3 \\
10 \\
1\end{array}$ & $\begin{array}{r}14 \\
12 \\
19 \\
5\end{array}$ & $\begin{array}{r}14 \\
11 \\
19 \\
5\end{array}$ & $\begin{array}{r}12 \\
11 \\
17 \\
5\end{array}$ & $\begin{array}{l}5 \\
6 \\
7 \\
3\end{array}$ \\
\hline $\begin{array}{c}\text { Total } \\
\%\end{array}$ & 60 & $\begin{array}{l}52 \\
86 \cdot 7\end{array}$ & $\begin{array}{l}43 \\
82 \cdot 7\end{array}$ & $\begin{array}{l}23 \\
53 \cdot 4\end{array}$ & 50 & $\begin{array}{l}49 \\
98.0\end{array}$ & $\begin{array}{l}45 \\
91 \cdot 8\end{array}$ & $\begin{array}{l}21 \\
46 \cdot 6\end{array}$ \\
\hline
\end{tabular}

Table 2. Calving rates following fixed-time insemination of heifers at the oestrus after withdrawal of progestagen-impregnated intravaginal pessaries inserted for 10 days

\begin{tabular}{|c|c|c|c|c|c|}
\hline \multirow{2}{*}{ Farm } & \multicolumn{3}{|c|}{ Progesterone-treated heifers } & \multicolumn{2}{|c|}{ Control heifers } \\
\hline & No. treated & No. inseminated & No. calving & No. inseminated & No. calving \\
\hline 1 & 36 & 34 & 17 & - & - \\
\hline 2 & 15 & 14 & 8 & 13 & 7 \\
\hline 3 & 12 & 12 & 10 & 13 & 5 \\
\hline 4 & 32 & 29 & 18 & 25 & 16 \\
\hline Total & 95 & $\begin{array}{c}89 \\
(93.6 \%)\end{array}$ & $\begin{array}{c}53 \\
\left(59 \cdot 6^{\circ} \%\right)\end{array}$ & 51 & $\begin{array}{c}28 \\
(54 \cdot 9 \%)\end{array}$ \\
\hline
\end{tabular}

There was no difference in the oestrous response of the heifers in Trial 1 after either treatment (Table 1), and the difference between the calving rates of the two groups was not significant $\left(\chi^{2}=0.35 ;\right.$ d.f. $\left.=1 ; P>0.10\right)$. The calving rate of the heifers treated with progesterone in Trial 2 was similar to that of the control group (Table 2).

The retention of the pessaries under farm conditions during the 10-day treatment period was high, confirming previous observations (Sreenan, 1975).

To be of value under farm conditions, oestrous cycle control treatments should eliminate the need for detection of oestrus and allow normal fertility rates after insemination on a fixed-time basis. Long-term progestagen treatments have resulted in reduced fertility levels at the controlled oestrus (Jochle, 1972). The use of oestrogens (Ulberg \& Lindley, 1960; Hansel et al., 1961) and 
gonadotrophins (Graves \& Dziuk, 1968; Boyd \& Tasker, 1971; Roche \& Crowley, 1973) in association with long-term progestagen treatments and fixedtime insemination procedures have generally resulted in further reductions in conception rates. Recent reports have indicated that if the period of progestagen treatment is reduced to about 10 days, fertility levels are normal at the controlled oestrus (Wiltbank \& Kasson, 1968; Wishart \& Young, 1974; Roche, 1974; Sreenan, 1975). Wishart \& Young (1974) recorded a pregnancy rate of $65.2 \%$ with a fixed-time insemination at the oestrus after a 9-day progestagen treatment. In the present study, a 10-day treatment, with initial oestrogen and progesterone, resulted in a calving rate $(59.6 \%)$ slightly above that of control heifers $(54.9 \%)$ after insemination at fixed times. This normal fertility is probably due to a precise control of ovulation.

It is possible that the use of gonadotrophins or releasing hormones in association with such short-term treatments may result in further control of ovulation and permit normal fertility levels after a single fixed-time insemination.

We thank Mr D. Wishart, G. D. Searle \& Co. Ltd, for the SC-9880 (Cronolone), Mr A. McDonagh for excellent technical assistance and Mr G. Morris and $\mathrm{Mr}$ P. Creaven for help at all stages of this work.

\section{REFERENCES}

BOYd, L.J. \& TAsker, J.B. (1971) Fertility of oestrus synchronized dairy cattle treated with gonadotrophins and inseminated at a predetermined time. Vet. Rec. 632-635.

Graves, C.N. \& Dziuk, P.J. (1968) Control of ovulation in dairy cattle with human chorionic gonadotrophin after treatment with $6 \alpha$-methyl-17 $\alpha$-acetoxy progesterone. $\mathcal{F}$. Reprod. Fert. 17, 169-172.

Hansel, W., Malven, P.V. \& Black, D.L. (1961) Estrous cycle regulation in the bovine. F. Anim. Sci. 20,621.

Jochle, W. (1972) Pharmacological aspects of the control of the cycle in domestic animals. Proc. 7th Int. Congr. Anim. Reprod. $\mathbb{B}^{\circ}$ A.I., Munich 1, 97-124.

RоснE, J.F. (1974) Effect of short-term progesterone treatment on oestrous response and fertility in heifers. F. Reprod. Fert. 40, 433-440.

Roche, J.F. \& Crowley, J.P. (1973) The fertility of heifers inseminated at a predetermined interval following treatment with MGA and HCG to control ovulation. F. Reprod. Fert. 35, 211-216.

SREENAN, J.M. (1974) Retention of intravaginal sponge pessaries by cattle. Vet. Rec. 94, 45-47.

SREENAN, J.M. (1975) Effect of long- and short-term intravaginal progestagen treatments on synchronization of oestrus and fertility in heifers. F. Reprod. Fert. 45, 479-485.

ULBERG, L.C. \& LindLEY, C.E. (1960) Use of progesterone and estrogen in the control of reproductive activities in beef cattle. F. Anim. Sci. 19, 1132.

WiLtBank, J.N. \& KAsson, C.W. (1968) Synchronization of oestrus in cattle with an oral progestational agent and an injection of an estrogen. F. Anim. Sci. 27, 113-116.

WishaRT, D.F. \& Hoskin, B.D. (1968) Synchronization of oestrus in heifers using intravaginal pessaries impregnated with SG-9880 and PMSG. F. Reprod. Fert. 17, 285-289.

WisharT, D.F. \& Young, I.M. (1974) Artificial insemination of cattle at a predetermined time following treatment with a potent progestin (SC-21009). Vet. Rec. 95, 503-508. 